\title{
FORMATIVE ASSESSMENT IN EFL CLASSROOM PRACTICES
}

\author{
Ida Ayu Made Sri Widiastuti dan Ali Saukah
}

Mahasaraswati Denpasar University dan Universitas Negeri Malang

\begin{abstract}
This study investigated the challenges and opportunities of formative assessment in EFL classes. It made use of qualitative research design by using indepth interviews to collect the required data. Three teachers and three students were involved as research participants in this study and they were intensively interviewed to get valid and reliable data regarding their understanding of formative assessment and the follow up actions they took after implementing formative assessment. The results of this study showed that the English teachers were found not to take appropriate follow up actions due to their low understanding of formative assessment. The teachers' understanding could influence their ability in deciding the actions. This study indicates that EFL teachers need urgent further intensive training on the appropriate implementation of formative assessment and how follow up actions should be integrated into classroom practices.
\end{abstract}

Keywords: Formative Assessment, EFL, Classroom Practices

\begin{abstract}
Abstrak: Penelitian ini mengkaji tantangan dan peluang penilaian formatif di kelas bahasa Inggris sebagai bahasa asing. Penelitian ini menggunakan desain penelitian kualitatif dengan mengunakan wawancara mendalam untuk mengumpulkan data yang dikehendaki. Tiga guru dan tiga siswa ikut serta menjadi partisipan penelitian ini dan mereka secara intensif diwawancarai untuk mendapat data yang valid dan reliabel mengenai pemahaman mereka terhadap penilaian formatif dan tindak lanjut yang dilakukan setelah penilaian formatif dilaksanakan. Hasil penelitian ini menunjukan bahwa guru-guru bahasa Inggris tidak melakukan tindak lanjut yang tepat karena pemahaman mereka terhadap penilaian formatif yang rendah. Pemahaman guru-guru dapat memengaruhi kemampuan mereka dalam menentukan tindak lanjut. Penelitian ini menunjukan bahwa guru-guru bahasa Inggris sebagai bahasa asing memerlukan pelatihan intensif lebih lanjut yang mendesak mengenai pelaksanaan penilaian formatif dan bagaimana tindak lanjut dari penilaian dintegrasikan ke dalam praktek di kelas.
\end{abstract}

Kata Kunci: Penilaian Formatif, Bahasa Inggris sebagai Bahasa Asing, Praktik di Kelas

Teaching and learning processes always consist of two main essential and inseparable activities, namely: teaching and assessment. The two cannot be separated since teaching is 
always followed by administering an assessment to get an insight into the students' ability and their understanding of the learning material taught. Moreover, assessment can be used to reinforce the students' learning achievement and to motivate the students to learn and develop their understanding of the learning material further and more deeply. It is also used as a tool to indicate whether the learning objectives have been achieved by the students or whether further intensive learning improvement should be made.

In classroom learning practices, teachers generally conduct two main types of assessment. They are formative and summative assessment. Dunn and Mulvenon (2009) point out that it is vital to deeply grasp the key concept of formative assessment because there is a lack of agreed definitions and limited empirical evidence concerning formative assessment practices. There is a lack of core concepts which distinguish formative assessment from other types of assessment. Therefore, in their study, the formative assessment and summative assessment is critically defined in context with educational purposes and formative assessment analysis is strongly focused on teachers' understanding and their follow up actions.

Formative assessment is considered one of the most influential ways to improve teaching and learning processes. This type of assessment is conducted to assess students' understanding, learning needs, and learning progress concerning a particular unit of learning materials (Karimi, 2014). Formative assessments can help teachers identify the areas of students' difficulty in understanding the learning materials, acquiring the essential skills that they need to achieve the learning competence (Ruiz-Primo \& Furtak, 2007; Newton, 2007). Formative assessment allows teachers to make adjustments and revision on learning materials and teaching techniques in order to be more successful in teaching. Heritage (2008: 2) states that formative assessment is intended to give feedback to the teachers and the students related to instructional processes and to oversee the gaps between the learning process and the desired learning outcomes (Elliott \& Yu, 2013; Good, 2011).

The main objective of formative assessment is merely to collect detailed information about the teaching and learning processes that can be utilized for further instructional improvement to attain the highest learning standard needed by the students to continue their learning (Newton, 2007; Filsecker \& Kerres, 2012). Formative assessment is essential because it helps teachers to make judgment on the students' ability and decide what improvement should be intensified in order that the students' learning achievement can reach the highest standard. In addition, Herman, Osmundson and Silver (2010) state that good quality of formative assessment is vital to improve the students' learning outcomes. Therefore, conducting formative assessment properly in classroom practices is vital for teachers.

As described above, formative assessment takes place during the teaching and learning activities and the primary objective is to help teachers to conduct more appropriate teaching and learning activities to enhance the students' learning achievement. In this case, it can be summed up that there are two important purposes of formative assessment: (a) determining and modifying learning activities, and (b) choosing the most appropriate strategies to improve the students' learning achievement. Filsecker and Kerres (2012) describe that the formative assessment components include teacher - student(s) moment to moment interactions, communicating to the students the criteria of success, gathering detail information about learning activities, providing learning feedback, and providing instructional corrective adjustments. It is essential that teachers understand these components of formative assessment to be able to properly carry out the formative assessment in classroom practices. 
Based on the above objectives, formative assessment can be characterized as follows: (a) it is an assessment carried out by teachers on a daily basis during the teaching and learning process; (b) it provides feedback for the teachers to do immediate revision; and (c) it aims at modifying teaching and learning activities in order to improve students' learning achievement. In line with the objectives of instructional processes, consequently, most classroom assessment is formative because it allows teachers to consider what improvement should be made immediately which will give significant learning impacts for the students in achieving the learning objectives completely (Decristan, et al., 2015; Dunn \& Mulvenon, 2009).

English teachers nowadays are required to have a good understanding of formative assessment. The understanding will certainly affect their ability in determining the follow up actions that they need to do to improve their students' learning achievement and develop their professional teaching practices. Teachers' understanding of formative assessment includes their understanding of the nature of formative assessment, the characteristics and the principles of formative assessment, ability in giving feedback and ability in doing the follow up actions. It is essential that teachers provide feedback properly in order that the students know about their learning progress so that they can modify their learning styles to improve themselves. As Black and Wiliam (2009) point out, teachers need to understand various theories on how the students learn and how to implement those theories in the classroom in order to be able to give appropriate feedback to the students related to their learning progress. Meanwhile, the follow up actions taken by teachers is even more important because these actions are actually the essence of formative assessment which directly benefit the students' learning.

Previous studies indicated the importance of formative assessment to improve the quality of the teaching and learning process in the classroom. A study conducted by RuizPrimo \& Furtak (2007) found that there were various types of formative assesments that can be used by teachers to gather detail information about the students' learning. Using various types of assessment would give better information reagarding the students' learning condition. This study indicates that teachers should be able to choose appropropiate types of formative assessments to obtain certain detail information about students' learning, so that they can make appropiate modifications with their teaching. However, there appears to be issues with teachers' understanding of formative assessment. Kuzel and Shumba (2011), for instance, found that teachers in their study had very little knowledge about formative assessment and had a negative attitude towards it. Consequently, most teachers could not use the formative assessment as a basis for improvement of their teaching. Similarly, an extensive study conducted by Foster and Poppers (2009) revealed that most teachers in his study could not design suitable formative assessment in their teaching practices. Most of the formative assessment forms were not constructed in line with the characteristics of formative assessment; rather, they were constructed merely to test the students' current ability.

Most of the studies conducted on formative assessment focused on the benefits and factors that may influence the classroom interaction and the impact of formative assessment on students' learning achievement. There has not been an in depth study conducted to describe in detail the teachers' understanding of formative assessment and how their understanding affects their ways in doing follow up actions. According to Black and William (2009), formative assessment is important for teachers, so that they can make decisions about instructional improvement. Formative assessment is not merely conducted to provide feedback to the students in order they can improve their learning, but it is also useful for the 
teachers to decide how to modify their teaching styles to suit the students' needs and to make the students achieve the learning objectives in a shorter period of time.

Teachers' understanding of formative assessment certainly affects the types of feedback they give as well as the follow up actions they take. Teachers' follow up actions in response to students' learning problems are compulsory to make learning activities successful and meaningful for students. Without appropriate actions, students' learning achievement will be stagnant. Teachers, therefore, need to have wide knowledge of assessment and learning theories. This is in line with what Bennet (2011) suggests, that teachers' understanding of assessing students' understanding is also dependent upon the teachers' cognitive ability in theories of learning. He further emphasizes that there might be a risk in conducting formative assessment without comprehensive understanding of learning theories.

Theoretically, teachers who have a good understanding of formative assessment would carry out appropriate follow up actions since their understanding would influence their ability to effectively implement these actions. However, some studies found that many teachers did not carry out formative assessment as what has been generally assumed by most educators. The discrepancy between teachers' understanding and the real classroom phenomenon may probably be due to several factors which may influence the teachers' capability in conducting suitable follow up actions.

Considering the phenomenon of formative assessment and the importance of deciding appropriate follow up actions motivate the researchers to conduct a study on formative assessment in EFL classroom practices. This present study aims at investigating intensively teachers' understanding of formative assessment and the follow up actions they take after implementing formative assessment as well as in what way these actions are influenced by their understanding of formative assessment.

\section{METHOD}

This study made use of qualitative research design to investigate the formative assessment practices in EFL classroom. The data were collected by using interviews with three junior high school English teachers and three junior high school students.

The participants were selected by confining the cases to teachers with the same educational background. In order to meet the purpose of this study, the participants were also required to fulfill the criteria of professional English teachers as indicated by their teaching qualification and teaching experience. The teachers participating in this study were those who have been teaching English in junior high schools ranging from 2 to more than 10 years. Selecting teachers based on their different lengths of teaching experiences enabled the researchers to obtain a great amount of data related to teachers' understanding of formative assessment and the follow up actions they carried out in real classroom setting of EFL classes. To ensure the authenticity of the collected data, the participants were not informed of the focus of the study until all the required data had been collected.

The required data were collected through in-depth semi structured interviews with the three English teachers and three students concerning the teachers' understanding of formative assessment and follow up actions taken by the English teachers after the implementation of formative assessment. The interviews were conducted in a relaxed and conducive atmosphere to ensure that the teachers felt free to express themselves and to give their explanation about formative assessment in their classroom practices. Various open-ended questions based on the interview guide were asked to the English teachers to find out their understanding of 
formative assessment and the follow up actions they took. The questions were arranged from general to more specific to make sure that the teachers could answer the questions appropriately and did not feel being interrogated by the researchers. The collected data were analyzed descriptively using an in depth qualitative analysis completed with detail descriptions and argumentation. Some excerpts from the interviews are quoted verbatim in the following section of findings.

\section{FINDINGS}

Based on the analysis of the result of the interviews conducted with the English teachers on their formative assessment practices, it was found that the English teachers had various understanding of formative assessment and several strategies of follow up actions. In this section, the main findings of this study which deals with teachers' understanding of formative assessment and the follow up actions taken are discussed briefly.

\section{Teachers' Understanding of Formative Assessment}

Formative assessment is mainly conducted by teachers in the teaching and learning process in order to modify their instructional activities to improve students' achievement. Therefore, a comprehensive understanding of formative assessment is essentially needed by teachers in order to be able to modify their teaching and learning activities. In this section, the three teachers' understanding of the nature of formative assessment and feedback given to the students is briefly discussed to provide overall views of the teachers' understanding of formative assessment.

\section{The Teachers' Understanding of the Nature of Formative A ssessment}

Based on the interviews conducted with the three junior high school teachers who taught in different grades, it was found that they had various understanding of formative assessment and different views of formative assessment purposes. Their different understanding of formative assessment was reflected in their teaching ability.

"For me formative assessment is conducted to determine the extent to which students understand the lesson. I usually do this assessment at the end of every 1 unit of learning material. Assessment which I have done usually conducted at the end of every 1 unit of learning. My teaching goal is to make the students understand the learning materials and not only to gain a high score during the learning activities." (Teacher A)

This statement indicates that Teacher A had some awareness of the purpose of formative assessment, that it is carried out for the students' learning improvement and achievement of the learning objectives. She had some understanding of the formative assessment principles and the purpose of formative assessment implementation although she seemed to still be using formative assessment to grade the students. This teacher used the result of the formative assessment to improve learning and conducted formative assessment in the end of every learning unit.

"Formative assessment which is done by myself is to determine the extent to which the indicators of learning have been achieved by my students. The results of this assessment can also determine the extent to which my students understand the lesson given in class. This assessment is conducted after discussing 1 topic of the lesson. I refer this kind of assessment as daily tests (ulangan harian)." (Teacher B) 
The excerpt of this interview indicates that Teacher B had utilized the result of formative assessment to improve learning and she used the formative assessment to give an indication of the achievement of learning objectives. However, she did not have a comprehensive understanding of formative assessment criteria. She was still using a test from textbook and the assessment was in the form of daily assessment commonly called Ulangan Harian. This teacher, in some sense, understood the purposes of formative assessment and utilized the result of formative assessment to measure the students' achievement. She conducted the assessment in every unit of the lessons.

“The purpose of this assessment is to determine the students' understanding about the topics and Ulangan Harian is a good test to indicate this achievement because the tests are already in the course book and they are related to the topics of the lessons to each session." (Teacher B)

The statement from teacher B indicates that her primary understanding of formative assessment concerned the objectives of formative assessment itself. She did not have adequate understanding of the essential principles and characteristics of the formative assessment. The objective of formative assessment she implemented was merely to know the students' achievement. This teacher showed an understanding of one particular objective of formative assessment, that is to know the students' learning achievement, but she neglected other important objectives of formative assessment. The students in her class focused on doing all the exercises in the course book.

"I am not familiar with the term of formative assessment; I usually carry out daily tests (ulangan harian) to know the students' achievement. I give the test to the students at the end of every topic being discussed. My goal of conducting daily tests is to determine the extent to which students understand the lesson given. On the other hand, I give the students a test because it is also a kind of main tasks to be carried out by the teachers as the mandate of the school principle, in order to make the teachers have better preparation to prepare their students to face the final exam." (Teacher C)

Teacher C could not clearly and explicitly describe her understanding of formative assessment. She could not explain in detail what is meant by formative assessment. She conducted student learning assessment mainly in the form of daily assessment and she did the assessment because she thought she had to do it as a teacher. Her main focus was to ensure the students pass the final exam rather than improve learning activities. This teacher focused on preparing the students for the final. She seemed to be deeply worried about the students' performance in the final examination, so she gave tests for the students' practice before the final examination.

The findings indicate that the teachers' understanding of formative assessment is of different natures. However, their understanding is still not sufficient. This can clearly be seen from how the formative assessment is conducted by the teacher. The ability of using appropriate test format is also a reflection of the teachers' understanding of formative assessment. The teachers seemed to have inadequate knowledge of various types of tests that should be used for formative assessment. They mainly used one particular type of tests. If they had had a good understanding of formative assessment, they would have utilized various forms of assessment.

"I use question-answer in teaching. Question-answer means after delivering the lesson I asked the students some short questions. If they listen to me, they would be able to answer my question and if they cannot answer then I can understand that they did not take anything from my teaching." (Teacher B) 
The result of the interview above shows that the teacher dominated the class by asking questions to the students without giving chances for the students to clarify the questions or asking other types of questions. The teacher, in this case, was rather dominating the class. To a certain degree this situation might lead to the teacher's being judgmental and could make the students reluctant to join the class. This indicates that teacher B did not really comprehensively understand the principles of formative assessment. In addition, a certain type of test might not be effective to assess the students. The teachers' low ability in assessing the students indicates that she did not have a good understanding of formative assessment.

"I believe that by questioning them prompt questions is a good way of giving students a push to learn. Questioning may make them aware of the importance of learning besides gives me indication of their ability." (Teacher C)

Teacher $\mathrm{C}$ believed that asking a series of questions after learning activities is important to arouse the students' learning awareness. She believed that the students would learn more if they could not answer the questions. Questioning was also used by the teacher to figure out the students' learning achievement. During the interviews teacher B and teacher C vividly explained that they usually asked closed-ended questions and open-ended questions to the students. Teacher $\mathrm{C}$ showed that her ability in assessing the students' learning progress was still low. This is as indication that her understanding formative assessment was still quite low too. She was, however, trying to give encouragement for the students to improve their learning achievement.

\section{Teachers' Understanding of Feedback on the Students' Learning Achievement}

Teachers 'ability in giving correct feedback on the students' learning accomplishment is a part of teachers' understanding of formative assessment. Appropriate feedback may certainly increase the students' willingness to learn more and build up their curiosity about something that they need to learn. The teachers in the study sometimes gave feedback to the students after implementing various types of formative assessment to provide them with some insight on their level of understanding.

According to the teachers, feedback is useful for the students to make them aware of their ability and inspire them to make further improvement. They gave feedback to the whole class or individual students mostly in the form of oral feedback rather than written feedback. Written feedback was occasionally given on the students' writing task. In reading task, the teachers involved the students to read aloud from the text book, and when the students mispronounced the English words, the teacher corrected the mistake directly.

"Of course feedback is important for students. I think if feedback is given, both students and the teacher become benefited. The students become very happy if the feedback is given individually. In giving feedback I usually tend to publicly inform my students about their achievement in learning of one particular topic and then discuss each student's weaknesses and strengths individually." (Teacher A)

"I usually ask my students questions to get information about their learning without making them feel shy or embrace; I ask questions each one individually in front of the class and encourage them to speak in English. I always tell them that we are all still learning English and there is no need to be shy. I talk to the students about the most frequent mistakes they make on the test, and ask them to make correction so that they don't repeat the same mistakes. I explain the correct answers and then ask them to make revision." (Teacher B) 
This is an example of positive written feedback given to the students by one of the teachers. It is important that teachers provide positive feedback to encourage the students to learn more and be willing to do what the teachers suggest. Moreover, the students will feel being looked after by the teacher during their hard time learning. This is essential for a more effective teaching and learning process.

"I usually give the students' score for their achievement in learning. I also try to give some feedback. It is not easy to give feedback for each individual students because there so many students in one class. I am not just teaching one class in a day. I usually teach two or three classes in a day. Most of my feedback is about how they improve their learning so they get a better score during the exam. However, sometimes I suggest them to learn more diligently at home so they can understand more about the lesson. Most of the time I just tell them what to learn at home so really well-pared themselves for upcoming exam."

This study also revealed that the teachers had difficulty in finding appropriate ways of giving feedback to make the students really aware of their weaknesses. This is because in some circumstances some students were reluctant to receive feedback openly in public and to follow up the feedback properly. On the other hand, the teachers felt pressured by the demand of the curriculum which required the students to be successful on the high stakes national exam. One of the teachers claimed during her interview that she had to "teach for the exam" even though she thought that it would be better for the students to have good understanding of the lesson rather than getting high score without proper understanding. Due to the pressure, the purpose of her assessment was merely to know the students' scores. She carried out formative assessment to determine whether the indicators of learning could be achieved by the students. The main goal was to find out the students' scores so they could prepare themselves better for the final exam.

\section{Follow up Actions after the Implementation of Formative Assessment}

Follow up action is an important thing for the teachers to do after implementing the formative assessment. As a matter of fact, the follow up action is a compulsory action to make essential improvements of the teaching and learning process. All three teachers in this study explained that they utilized the formative assessment results to make several changes to their teaching styles. They described that they used the results as the basis to develop their teaching strategy, teaching technique and learning material for upcoming lesson. Teacher A said she tends to change her teaching strategy to group discussion in order to give more opportunities for the students to discuss the lesson that they could not understand. The students were always encouraged to do more exercises and to practice their English more frequently.

"I usually give formative assessment at the end of every topic of the lesson. I know students' achievement after giving the test. I use the result of the test for further improvement in teaching to develop the students' achievement in achieving the learning objectives." (Teacher B)

"I change my teaching style and develop my teaching material to be more contextual to the students' learning environment. I design the material from the easier to the more difficult material and also design a better instructional media to help me teaching." (Teacher B)

Teacher B made use of the formative assessment results to do a follow up action by revising her teaching preparation especially in developing instructional material, media and strategy that suited the students' needs better. In designing material, teacher B made a great attempt to contextualize the material to the students' learning environment including 
adopting some learning material based on local geniuses. Video was used by the teacher as part of her teaching improvement in terms of using more creative and innovative instructional media for listening and speaking. Peer discussion and group discussion were incorporated in learning activity as a follow up action after considering the results of formative assessment. In addition, exercises were also given to the students to increase the students' understanding of the lesson. Homework should also be done properly at home.

"For me conducting formative assessment is useful because I can make some revisions and improvement on my teaching practices, so that the learning objectives can be achieved successfully and completely." (Teacher C)

"The formative assessment is useful for me and the students to know about the intensity of the learning activity. I can use the result of the formative assessment to modify my teaching strategy and develop my teaching material to be more suitable for the students to make them understand the lesson easily." (Teacher C)

"I use group and peer discussion to make the students to communicate in English comfortably. My students like talking to each other once they are in group. I go around observing the students and giving guidance when needed." (Teacher $\mathrm{C}$ )

Teacher $\mathrm{C}$ had insufficient understanding of the follow up actions to be taken after formative assessment implementation. Her teaching focus was to make the students do all exercises in the students' workbook or $L K S$. She only occasionally gave feedback on the students' achievement. In addition, she rarely returned the students' assignments. Explanation was only given to the students when they had a serious misunderstanding of the lesson. She was, however, willing to do a personal approach to those students who had poor ability or difficulty in doing certain assignments. She often called the students to her office to have more private lesson.

Other teachers also did the informal learning approach as a follow up action. The teachers often asked the students to come to their office. This approach was especially used with the students who had low ability and those who needed special attention. It was done to make the students feel relaxed and comfortable in discussing the lesson and express their learning problems.

The results of the interviews conducted with the students confirmed that some follow up actions had been taken by the teachers. The students described that the teachers gave them more exercises to do and sometimes asked them to work in group.

"My teachers seem more eager to teach us recently. She gave me a lot more exercises. She sometimes explains to me the answers. She often asks me about my problems in studying English. When I am shy to tell my problem in the class, she asked me to come to her office to tell my problems and sometimes she gave me some more explanation about the lesson. I like it because my friends do not know what my problems are"

This excerpt of the students' interviews indicates that the students were really happy that the teachers made some changes on their teaching strategy. The students were glad that they could receive extra lesson from the teachers in their office. The students found this a friendly way of learning and they were not feeling afraid of bad opinion from their friends that they actually had problems in learning. 


\section{DISCUSSION}

Formative assessment administration is not only useful to find out the students' problems in learning, but it is also essential for the teachers themselves to improve their teaching styles in order that the learning activities can become more effective in enhancing the students' knowledge and skills. It was found in the study that the teachers' understanding of formative assessment really influenced their ability to conduct the formative assessment in their teaching practice. The teachers are expected to be able to conduct formative assessment in line with the principles of formative assessment and carry out appropriate follow up actions to improve the teaching and learning process.

Good (2011) explains that formative assessment is used to gather information related to appropriate learning content, context, and learning strategies and to fill the existing gaps between the students' current performance and the targeted learning goal. Formative assessment helps teachers become aware of any gaps that exist between their desired goal and their current knowledge, understanding, or skill and guides them through actions necessary to obtain the goal (Viktorovna \& Arkadyevna, 2015). Therefore, having a comprehensive understanding of formative assessment becomes an essential thing for teachers to decide effective follow up actions.

Based on the findings, teachers A and B appeared to have quite some understanding of formative assessment. They had done some revision on their teaching styles which brought the students to learn for understanding rather than just getting high scores in the final exam. They involved the students in various contextual learning activities to develop the students' understanding and contextualize the material. However, these teachers still relied on using daily assessment as a formative assessment. This daily assessment is commonly called "Ulangan Harian". This type of assessment was probably intended to measure the students' understanding of a certain topic. In this case, the teachers still need to upgrade their understanding of formative assessment. Black and Wiliam (2009) mention that formative assessment is intended to do diagnosis, prediction, and evaluation of teacher and students' performance.

This study revealed that the teachers' understanding of formative assessment in a certain way affected their teaching styles. The teachers made use of the formative assessment result to do some follow up actions to improve the teaching and learning processes. The teachers have some understanding on formative assessment principles since they have to continually improve their teaching strategy to fulfill the students' need to face the new development. Formative assessment can be used as a stepping stone to do proper follow up actions (RuizPrimo, 2011; Forbes, Sabel, \& Biggers, 2015). Formative assessment may develop new model of learning and affect decision making process or follow up actions determined by the teachers. The development model may relate to teachers' ability in learning preparation and implementation (McMillan, Venable, \& Varier, 2013).

In regard to the teachers' understanding of formative assessment, the teachers are mainly required to utilize the result of formative assessment for improvement of learning activities. It is not for grading the students. Asghar (2013) points out that there are a lot of aspects that determine whether formative assessment can serve as a useful tool to modify pedagogical practices. These include the assessment administrators, assessment atmosphere, students' engagement, and teachers' involvement. Asghar further explains that formative assessment is conducted by the teachers during the learning process in order to modify teaching and learning activities to improve student attainment. The formative assessment is intended to 
accelerate students' achievement and to help predict how well students will perform on upcoming lessons (Schneider \& Andrade, 2013).

The formative assessment understanding of teachers A and B can be clearly seen from the way they determined the follow actions. Some follow up actions were taken by the teachers such as changing their teaching strategy, giving feedback to the students, developing learning materials, and inviting the poor students to have more private instruction in the teacher's office. The follow up actions were taken as a response to the results of the formative assessment which indicated that some students had low ability and low motivation in learning. Formative assessment helps teachers to know the students' ability and the students' problems in learning. Therefore, teachers' knowledge and skill in teaching and assessment need to be improved continuously. Nicol and Macfarlane-Dick (2006) suggest that teachers' knowledge in assessment affects their way of teaching their students in class. The knowledge is fundamental in shaping teachers' decision making.

Teachers' knowledge of formative assessment gives much contribution to their ability in preparing the lesson, conducting the teaching and learning process and understanding students' problems in learning. In this study the three teachers were unable to conduct formative assessment and follow up actions properly. In this study, only teacher A and teacher B had done some changes on their teaching after implementing formative assessment; however, these improvements were made occasionally and were not maintained up to maximum level of improvement to attain high quality of learning.

In line with the above description, Wiggins and McTighe (2005) describe that formative assessments give the teachers information about how teaching and learning activities should be conducted in a learning classroom. Some students simply need more practice than others to master knowledge or skills (Decristan, et al., 2015). Formative assessment result in this case can be used to analyze the extent of the students' achievement in learning. It is conducted to see how close the students have attained the learning target and whether some revisions need to be done by the teachers. Consequently, the teachers really need to comprehensively understand the fundamental principles of formative assessment. This means that the teachers' understanding of the result of formative assessment and their ability to interpret the result to do follow up actions properly are certainly beneficial for the improvement of the teaching and learning activities.

In addition, teachers' ability in giving correct feedback is an essential part of formative assessment understanding as stated by McManus (2008: 3) that formative assessment is a process carried out by the teachers and students in the classroom to provide feedback on the teaching and learning process in order to improve the students' learning achievement and to achieve the instructional objectives. In this study the teachers provided only oral feedback to the students. The oral feedback sometimes was not really effective for the students because many students did not retain what had been told by the teacher. Consequently, the feedback could not be used by the students for improvement of their study as they simply forgot what the feedback was about. Moreover, the interviews indicated that the feedback given to the students was merely about how to improve their learning strategy to get a high score in final exam.

The students in this study, however, also felt that the teachers had made some positive changes on their way of teaching. The teachers sometimes asked them to work in groups to discuss the exercises. The students believe that group discussion is a new strategy of learning that makes them understand the lesson more. The students also felt that in certain ways the teachers were getting friendlier to them. An example would be when the students were invited 
to come to their office to discuss their problems. The students were happy with this and responded positively. This way of approaching the students might be quite effective for Indonesian students because many students are still shy to tell their problems in front of others.

The interviews also revealed that the teachers felt pressured by the stakeholders' requirement to teach the students to get high score in national exams because the score of the national examination is used as an indicator of successful learning institution in Indonesia. This pressure made the teachers reluctant to change their teaching styles. They preferred to focus the teaching and learning process on ensuring that the students pass the final examination rather than to make sure that the students have comprehensive understanding of the content of the lesson. The teachers in this study were often influenced by the school norms in making classroom decisions and in taking follow-up actions after implementing formative assessment.

The study revealed that the reason for the follow up actions taken by the teachers is mainly due to the need of the school to prepare the students for final examination (high stakes exam). The teachers claimed that there were too many topics to be taught for final examination; that is why they had very little time to do proper follow up actions after implementing formative assessment. They said it is safer for them to do what is required by the stakeholders because they do not want to be blamed if the students fail in the national examination.

It seems that the teachers in this study are still confused in terms of their understanding of the real purposes of formative assessment. OECD (2005) describes that teachers should frequently carry out formative assessment to figure out the students' progress, to understand their learning needs and to modify teaching to suit the learning development of the students and the desired outcomes (Elliott $\& Y u, 2013$ ). This indicates that formative assessment is more than making the students to obtain a high grade in the final examination.

The above discussion indicates that the English teachers in this study do not have comprehensive understanding of formative assessment yet; consequently, the follow up actions are not properly carried out. Several improvements have been done by the teachers after conducting formative assessment; however, these were not done in various high quality activities. The teachers focused on teaching all the material in the course book. The teaching strategies selected by the teachers did not really support a good implementation of communicative teaching. The teacher only changed their teaching method to group discussion. There are many other more effective teaching methods that the teachers can use to improve their teaching which are more communicative and contextual for the students so that they are willing to learn more intensively and actively.

\section{CONCLUSIONS}

Lack of the teachers' understanding about the strategic role of formative assessment apparently leads to the teachers' not taking appropriate actions to follow up feedback obtained from assessment to improve the learning and teaching processes for better achievement. Proper understanding of formative assessment and appropriate follow up actions taken by the teachers will improve the students' learning achievement and at the same time will lead them to pass the final examination with good scores.

The teachers' understanding of formative assessment needs to be continuously improved. Better understanding of formative assessment and the ability to do follow up actions properly will make the 
assessment programs meaningful for the teachers and the students. The teachers will become more reflective teachers and students will be motivated to learn more to achieve the instructional goals which will help them attain higher achievement.

\section{REFERENCES}

Asghar, M. 2013. Exploring Formative Assessment Using Cultural Historical Activity Theory. Turkish Online Journal of Qualitative Inquiry, 4 (2): 18-32.

Assessment perspective: A Response to Dunn \& Mulvenon (2009). Practical Assessment, $\begin{array}{lllll}\text { Research \& } \quad \text { Evaluation, } 17 \text { (16). Retrieved from } & \text { \& }\end{array}$ http://pareonline.net/getvn.asp?v=17\&n=16

Bennet, R. E. 2011. Formative Assessment: A Critical Review. Assessment in Education: Principles, Policy \& Practice, 18 (1): 5-25.

Black, P., \& Wiliam, D. 2009. Developing the Theory of Formative Educational Assessment, Evaluation and Accountability, 21 (1): 5-31.

Decristan, J., et al. 2015. Embedded Formative Assessment and Classroom Process Quality: How Do They Interact in Promoting Science Understanding? American Educational Research Journal, 52 (6): 1133-1159.

Dunn, K. E., \& Mulvenon, S. W. 2009. A Critical Review of Research on Formative Assessments: The Limited Scientific Evidence of the Impact of Formative Assessments in Education. Practical Assessment \& Research and Evaluation, 14 (7): 1-11.

Elliott, J., \& Yu, C. 2013. Learning Studies in Hong Kong Schools: A Summary Evaluation Report on the 'Variation for the Improvement of Teaching and Learning' (VITAL) Project. Education and Didactique, 7 (2): 147-163.

Filsecker, M., \& Kerres, M. 2012. Repositioning formative assessment from an educational

Forbes, C. T., Sabel, J. L., \& Biggers, M. 2015. Elementary Teachers' Use of Formative Assessment to Support Students' Learning about Interactions between the Hydrosphere and Geosphere. Journal of Geoscience Education, 63 (3): 210-221.

Foster. D., \& Poppers, A. 2009. Using Formative Assessment to Drive Learning. Silicon Valley: The Noyce Foundation.

Heritage, M. 2008. Learning Progressions: Supporting Instruction and Formative Assessment. Washington, DC: Chief Council of State School Officers.

Good, R. 2011. Formative Use of Assessment Information: It's a Process, So Let's Say What We Mean. Practical Assessment, Research \& Evaluation, 16 (3). Retrieved from http://pareonline.net/getvn.asp? $\mathrm{v}=16 \& \mathrm{n}=3$

Herman J. L., Osmundson, E., \& Silver, D. 2010. Capturing Quality in Formative Assessment Practice: Measurement Challenges. Los Angeles: University of California.

Karimi, M. N. 2014. Iranian EFL Teachers' Perceptions of Dynamic Assessment: Exploring the Role of Education and Length of Service. Australian Journal of Teacher Education, 39 (8): 143-162.

Kuzel, M.W., \& Shumba, A. 2011. An Investigation into Formative Assessment Practices of Teachers in Selected Schools in Fort Beaufort in South Africa. J Soc Sci Journal, 29 (2): 159-170.

McManus, S. (Ed.). 2008. Attributes of Effective Formative Assessment. Washington, DC: Council of Chief State School Officers. 
McMillan, J. H., Venable, J. C., \& Varier, D. 2013. Studies of the Effect of Formative Assessment on Student Achievement: So much more is needed. Practical Assessment, Research \& Evaluation, 18 (2): 1-15.

Newton, P. E. 2007. Clarifying the Purposes of Educational Assessment. Assessment in Education: Principles, Policy \& Practice, 14 (2): 149-170.

Nicol, D. J., \& Macfarlane-Dick, D.2006. Formative Assessment and Self-Regulated Learning: A Model and Seven Principles of Good Feedback Practice. Studies in Higher Education, 31 (2): 199-218.

OECD (Office of Economic Co-operation and Development). 2005. Formative Assessment: Improving Learning in Secondary Classrooms. Paris: OECD Publishing.

Ruiz-Primo, M. A. 2011. Informal Formative Assessment: The Role of Instructional Dialogues in Assessing Students' Learning. Studies In Educational Evaluation, 37 (1): 15-24.

Ruiz-Primo, M. A., \& Furtak, E. M. 2007. Exploring Teachers' Informal Formative Assessment Practices and Students' Understanding in the Context of Scientiific Inquiry. Journal of Research in Science Teaching, 44 (1): 57-84.

Schneider, M. C., \& Andrade, H. 2013. Teachers' and Administrators' Use of Evidence of Student Learning to Take Action: Conclusions Drawn from a Special Issue on Formative Assessment. Applied Measurement in Education, 26 (3): 159-162.

Viktorovna, K. M., \& Arkadyevna, S. L. 2015. Formative Assessment as a Component of the Future English Teacher Training. International Education Studies, 8 (8): 157-165.

Wiggins, G., \& McTighe, J. 2005. Understanding by Design (2nd ed.). Alexandria, VA: Association for Supervision and Curriculum Development. 